\title{
Effects of azathioprine on response of renal anaemia to subcutaneous recombinant human erythropoietin
}

J E Howarth, H M Waters, D Shanks, K Hyde, J A Liu Yin, C G Geary, E Anastassiades, D Howarth, R Gokal

\begin{abstract}
Aims: To determine the effect of concomitant azathioprine treatment on the response of patients with renal failure to treatment with subcutaneous recombinant human erythropoietin (r-HuEPO).

Methods: Two groups of patients with renal failure not receiving haemodialysis were studied. One comprised seven patients receiving erythropoietin alone, the second consisted of nine patients who were also treated with azathioprine. The haematological changes were monitored, and the functional erythropoietic response was studied by two different ferrokinetic models. One analysed the initial, the other the extended plasma iron clearance. Studies were performed before r-HuEPO treatment on all 16 patients, and repeated on 11 of these when the target haemoglobin (10-11 g/dl) was achieved and stabilised. Total erythropoiesis was determined using both techniques. Analysis of the extended plasma iron clearance also permitted calculation of both effective and ineffective erythroid

(F Clin Pathol 1993;46:41-44)

Erythropoietin influences the differentiation of committed erythroid progenitor cells into erythroblasts. Its principal effect is to induce the proliferation of erythroid colony forming units (CFU-E) and their subsequent maturation into proerythroblasts. 'A secondary effect may also include the differentiation of erythroid burst forming units (BFU-E). Inability to produce erythropoietin is the main cause of the characteristic anaemia of end-stage renal disease. ${ }^{23}$ Additional contributory factors may be reduced red cell survival and, possibly, the retention of erythropoietic inhibitors. ${ }^{4-7}$ With the advent of recombinant DNA technology, large quantities of purified human erythropoietin are now available. ${ }^{89}$ Previous clinical trials $^{10} 15$ have reported the efficacy of recombinant erythropoietin for treatment of the anaemia of renal failure, the functional response being identified by application of ferrokinetic models based on analysis of either the initial or the extended plasma iron clearance lines. ${ }^{1017}$
\end{abstract} activity.

Results: The haematological response to r-HuEPO was the same for both patient groups. Measurement of total erythropoiesis by both ferrokinetic methods showed good correlation. For those receiving long term azathioprine, the percentage ineffective erythropoiesis was high compared with that of the other patients, and remained so for as long as they continued with azathioprine. For those uncomplicated by azathioprine treatment, r-HuEPO increased levels of both effective and ineffective erythropoiesis by the same degree. A substantial reduction in ineffective erythropoiesis was shown only by those patients who either discontinued or reduced their azathioprine once they started r-HuEPO treatment.

Conclusions: Azathioprine increases ineffective erythropoiesis. In this study, the r-HuEPO dose was sufficient to overcome this effect and promoted effective erythropoiesis so that the anaemia lessened. Measurement of total erythropoiesis provided limited information on the functional changes involved, differentiation of effective from ineffective erythropoiesis being necessary to define the changes after azathoprine reduction or withdrawal.

\section{Methods}

Pretreatment ferrokinetic studies were performed on 16 patients with end-stage renal disease who were receiving r-HuEPO. Eleven (cases 1-4 and 8-14) did not require dialysis; five (cases 5-7, 15 and 16) were receiving continuous ambulatory peritoneal dialysis (CAPD). For the pre-dialysis group, the initial dose was 120 units $/ \mathrm{kg}$ body weight/week, administered as two 60 unit subcutaneous injections; doses for the CAPD group comprised 100 units/kg body weight/week in two 50 unit aliquots. For both groups, the drug was self-administered. Doses were adjusted according to response to achieve a stable haemoglobin concentration of between 10 and $11 \mathrm{~g} / \mathrm{dl}$.

Patients without iron overload (serum ferritin of $<500 \mu \mathrm{g} / \mathrm{l})$ received $300 \mathrm{mg}$ elemental iron/day; those with high serum ferritin concentrations were not given supplements unless the serum ferritin dropped to less than $200 \mu \mathrm{g} / \mathrm{l}$. For patients unable to tolerate oral iron, $250-500 \mathrm{mg}$ iron-dextran complex was administered by slow intravenous injection over 20 to 40 minutes.

When pretreatment ferrokinetic studies were performed, nine patients were also receiving azathioprine (table 1), eight of whom had failing renal transplants and required aza- 
thioprine to suppress chronic rejection of their transplanted kidneys. The maintenance dose was regulated according to both the patient's body weight and any myelosuppressive effects indicated by the blood count parameters. In the case of two patients (cases 12 and 15), azathioprine was withdrawn during the course of r-HuEPO treatment; for four patients (cases $10,11,13$ and 14), azathioprine concentrations were reduced; the dose was unchanged for the remaining three (cases 8, 9 and 16). Ferrokinetic studies were carried out before $\mathrm{r}-\mathrm{HuEPO}$ was administered on all 16 patients, and studies after treatment were performed on 11 when the target haemoglobin concentration had been achieved and had remained stable. We were unable to carry out such studies on five patients; three (cases 3, 14, and 15) were poor compliers with the self-administration of r-HuEPO, one (case 2) required dialysis, and one (case 16) died.

${ }^{59} \mathrm{Fe}$ labelled transferrin was prepared, ${ }^{18}$ and $4 \mathrm{ml}$ plasma containing between 0.2 and 0.4 $\mathrm{MBq}$ of label was injected intravenously. Venous blood samples were collected at timed intervals over the next 14 days. Total erythroid activity was determined from analysis of the initial plasma iron clearance as a measurement of erythron transferrin uptake (ETU), ${ }^{16}$ and from analysis of the extended plasma iron clearance as the marrow iron turnover (MIT). ${ }^{17}$ The latter technique also permitted calculation of effective erythropoiesis, denoted by the red cell iron turnover (RCIT), and ineffective erythropoiesis, denoted by the ineffective iron turnover (IIT). ${ }^{17}$

Red cell volume (RCV)and red cell survival (RCS) were both measured by recommended methods. ${ }^{1920}$ Plasma volume (PV) was determined by dilution of ${ }^{59} \mathrm{Fe}$ labelled transferrin in the plasma compartment. ${ }^{21}$

Venous blood samples were stained for reticulocytes using a modification of the method of Dacie and Lewis. ${ }^{22}$ A 50:50 mixture of whole blood and $0.5 \%$ new methylene blue was prepared. After 7 minutes at room temperature, a reticulocyte smear was prepared and counted using a microscope fitted with a graticule in one eyepiece. The reference value shown in table 1 is that routinely used for clinical purposes.

Serum ferritin concentrations were measured using an enzyme linked immunosorbent assay (ELISA). ${ }^{23}$

\section{Results}

Pre- and post-treatment haematological and ferrokinetic data are shown in tables 1 and 2 . For the 11 patients on whom both studies before and after treatment were performed, the red cell volume increased (mean pre-treatment value 0.841 ; mean post-treatment value 1.431 ) as r-HuEPO stimulated the effective component of erythropoiesis (mean pre-treatment RCIT $40.1 \mu \mathrm{mol} / 1$ blood $/ 24 \mathrm{~h}$; mean posttreatment RCIT $66.2 \mu \mathrm{mol} / 1 \mathrm{blood} / 24 \mathrm{~h}$ ). The absolute reticulocyte count, which was regularly monitored throughout the first month following treatment, showed a sustained increase during this time period (mean pre-treatment value $27 \times 10^{9} / 1$; mean posttreatment value $62 \times 10^{9} / 1$.

Changes in the level of ineffective erythropoiesis (IIT) were less clearly defined. For patients receiving azathoprine, pre-treatment values for percentage ineffective erythropoiesis (IIT\%) were much higher than those observed for patients not receiving this drug. The mean pre-treatment value for IIT\% in those taking azathioprine was $58 \cdot 7 \%$ (range $49-69 \%$ ); for those not receiving azathioprine, this value was $36.0 \%$ (range $24-48 \%$ ).

For those not treated with azthioprine, the pre- and post-r-HuEPO treatment values remained essentially unchanged (mean pretreatment IIT\% 39.2\%; mean post-treatment IIT $\% 38 \cdot 2 \%)$. However, a mixed response was

Table 1 Haematological data

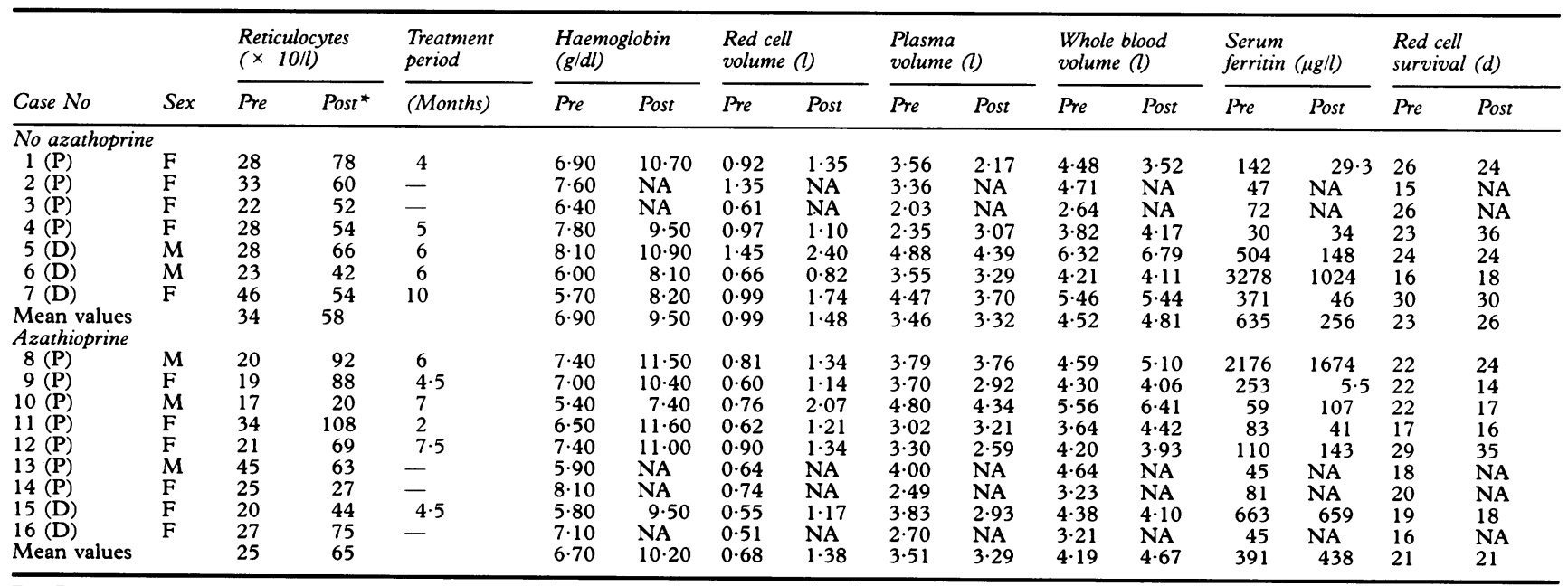

$\mathrm{P}=$ Predialysis patient; ${ }^{\star}=$ reticulocyte results following 1 month's treatment; $\mathbf{D}=$ CAPD patient; NA = result not available;

reference ranges

Reticulocytes $<100\left(10^{\circ} / 1\right)$

Haemoglobin Men 13-18 g/dl

Women $11.5-16.5 \mathrm{~g} / \mathrm{dl}$

Serum ferritin Men 15-200 $\mu \mathrm{g} / 1$

Red cell survival 25-33 d 
Table 2 Ferrokinetic data

\begin{tabular}{|c|c|c|c|c|c|c|c|c|c|c|c|c|}
\hline \multirow[b]{2}{*}{ Case No } & \multirow[b]{2}{*}{ Sex } & \multirow{2}{*}{$\begin{array}{l}\text { Treatment } \\
\text { period } \\
\text { (months) }\end{array}$} & \multicolumn{2}{|c|}{$\begin{array}{l}E T U \\
(\mu \mathrm{mol} / \mathrm{l} \text { blood/24 h) }\end{array}$} & \multicolumn{2}{|c|}{$\begin{array}{l}\text { MIT } \\
(\mu \mathrm{mol} / \mathrm{l} \text { blood/24 h) }\end{array}$} & \multicolumn{2}{|c|}{$\begin{array}{l}\text { RCIT } \\
(\mu \mathrm{mol} / \mathrm{l} \mathrm{blood} / 24 \mathrm{~h})\end{array}$} & \multicolumn{2}{|c|}{$\begin{array}{l}\text { IIT } \\
(\mu \mathrm{mol} / \mathrm{l} \text { blood/24h) }\end{array}$} & \multicolumn{2}{|c|}{$\begin{array}{l}I I T(\%) \\
(\mu \mathrm{mol} / \mathrm{l} \text { blood } / 24 h)\end{array}$} \\
\hline & & & Pre & Post & Pre & Post & Pre & Post & Pre & Post & Pre & Post \\
\hline $\begin{array}{l}\text { No azathoprine } \\
1 \text { (P) } \\
2 \text { (P) } \\
3 \text { (P) } \\
4 \text { (P) } \\
5 \text { (D) } \\
6 \text { (D) } \\
7 \text { (D) } \\
\text { Mean values }\end{array}$ & $\begin{array}{l}\mathrm{F} \\
\mathrm{F} \\
\mathrm{F} \\
\mathrm{F} \\
\mathrm{M} \\
\mathrm{M} \\
\mathrm{F}\end{array}$ & $\begin{array}{r}4 \\
- \\
5 \\
6 \\
6 \\
10\end{array}$ & $\begin{array}{l}26 \cdot 70 \\
27 \cdot 30 \\
45 \cdot 00 \\
20 \cdot 30 \\
31 \cdot 50 \\
12 \cdot 70 \\
23 \cdot 30 \\
26 \cdot 70\end{array}$ & $\begin{array}{l}76 \cdot 00 \\
\text { NA } \\
\text { NA } \\
47 \cdot 70 \\
58 \cdot 50 \\
45 \cdot 30 \\
46 \cdot 80 \\
54 \cdot 90\end{array}$ & $\begin{array}{l}87 \cdot 00 \\
52 \cdot 00 \\
76 \cdot 00 \\
64 \cdot 00 \\
77 \cdot 00 \\
34 \cdot 00 \\
62 \cdot 00 \\
64 \cdot 60\end{array}$ & $\begin{array}{l}144 \cdot 00 \\
\text { NA } \\
\text { NA } \\
72 \cdot 00 \\
104 \cdot 00 \\
78 \cdot 00 \\
87 \cdot 00 \\
97 \cdot 00\end{array}$ & $\begin{array}{l}45 \cdot 00 \\
33 \cdot 00 \\
58 \cdot 00 \\
41 \cdot 00 \\
54 \cdot 00 \\
21 \cdot 00 \\
35 \cdot 00 \\
41 \cdot 00\end{array}$ & $\begin{array}{l}78 \cdot 00 \\
\text { NA } \\
\text { NA } \\
50 \cdot 00 \\
69.00 \\
51.00 \\
48.00 \\
59.20\end{array}$ & $\begin{array}{l}42 \cdot 00 \\
19 \cdot 00 \\
18 \cdot 00 \\
23 \cdot 00 \\
23 \cdot 00 \\
13 \cdot 00 \\
27 \cdot 00 \\
23 \cdot 60\end{array}$ & $\begin{array}{l}66 \cdot 00 \\
\text { NA } \\
\text { NA } \\
22 \cdot 00 \\
35 \cdot 00 \\
27 \cdot 00 \\
39 \cdot 00 \\
37 \cdot 80\end{array}$ & $\begin{array}{l}48 \cdot 00 \\
37 \cdot 00 \\
24 \cdot 00 \\
36 \cdot 00 \\
30 \cdot 00 \\
33 \cdot 00 \\
44 \cdot 00 \\
36 \cdot 00\end{array}$ & $\begin{array}{l}46 \cdot 00 \\
\text { NA } \\
\text { NA } \\
31 \cdot 00 \\
34 \cdot 00 \\
35 \cdot 00 \\
45 \cdot 00 \\
38 \cdot 20\end{array}$ \\
\hline $\begin{array}{l}\text { Azathioprine } \\
8(\mathrm{P})^{\star} \\
9(\mathrm{P})^{\star} \\
10(\mathrm{P})^{\star \star} \\
11(\mathrm{P})^{\star \star} \\
12(\mathrm{P})^{\star \star \star} \\
13(\mathrm{P}) \\
14(\mathrm{P}) \\
15(\mathrm{D}){ }^{\star \star \star} \\
16(\mathrm{D}) \\
\text { Mean values }\end{array}$ & $\begin{array}{l}M \\
F \\
M \\
F \\
F \\
M \\
F \\
F \\
F\end{array}$ & $\begin{array}{l}6 \\
4 \cdot 5 \\
7 \\
2 \\
7 \cdot 5 \\
- \\
- \\
4 \cdot 5 \\
-\end{array}$ & $\begin{array}{r}40 \cdot 60 \\
44 \cdot 00 \\
66 \cdot 00 \\
81 \cdot 00 \\
66 \cdot 40 \\
107 \cdot 00 \\
65 \cdot 50 \\
68 \cdot 20 \\
54 \cdot 00 \\
65 \cdot 90\end{array}$ & $\begin{array}{c}47 \cdot 00 \\
104 \cdot 00 \\
118 \cdot 00 \\
87 \cdot 00 \\
98 \cdot 00 \\
\text { NA } \\
\text { NA } \\
72 \cdot 40 \\
\text { NA } \\
87 \cdot 70\end{array}$ & $\begin{array}{r}78 \cdot 00 \\
60 \cdot 00 \\
99 \cdot 00 \\
115.00 \\
109 \cdot 00 \\
150 \cdot 00 \\
129 \cdot 00 \\
111.00 \\
97 \cdot 00 \\
105 \cdot 00\end{array}$ & $\begin{array}{l}123 \cdot 00 \\
219 \cdot 00 \\
139 \cdot 00 \\
150 \cdot 00 \\
123 \cdot 00 \\
\text { NA } \\
\text { NA } \\
91 \cdot 00 \\
\text { NA } \\
141.00\end{array}$ & $\begin{array}{l}32 \cdot 00 \\
30 \cdot 00 \\
40 \cdot 00 \\
51 \cdot 00 \\
49 \cdot 00 \\
46 \cdot 00 \\
57 \cdot 00 \\
42 \cdot 00 \\
37 \cdot 00 \\
42 \cdot 70\end{array}$ & $\begin{array}{l}43 \cdot 00 \\
78 \cdot 00 \\
85 \cdot 00 \\
83 \cdot 00 \\
82 \cdot 00 \\
\text { NA } \\
\text { NA } \\
61 \cdot 00 \\
\text { NA } \\
72 \cdot 00\end{array}$ & $\begin{array}{r}46 \cdot 00 \\
30 \cdot 00 \\
59 \cdot 00 \\
64 \cdot 00 \\
60 \cdot 00 \\
104 \cdot 00 \\
72 \cdot 00 \\
69 \cdot 00 \\
60 \cdot 00 \\
62 \cdot 70\end{array}$ & $\begin{array}{c}80 \cdot 00 \\
141 \cdot 00 \\
54 \cdot 00 \\
67 \cdot 00 \\
41 \cdot 00 \\
\text { NA } \\
\text { NA } \\
30 \cdot 00 \\
\text { NA } \\
68 \cdot 80\end{array}$ & $\begin{array}{l}59 \cdot 00 \\
49 \cdot 00 \\
60 \cdot 00 \\
56 \cdot 00 \\
55 \cdot 00 \\
69 \cdot 00 \\
56 \cdot 00 \\
62 \cdot 00 \\
62 \cdot 00 \\
58 \cdot 70\end{array}$ & $\begin{array}{l}64 \cdot 00 \\
64 \cdot 00 \\
39 \cdot 00 \\
45 \cdot 00 \\
33 \cdot 00 \\
\text { NA } \\
\text { NA } \\
33 \cdot 00 \\
\text { NA } \\
46 \cdot 30\end{array}$ \\
\hline
\end{tabular}

$P=$ Predialysis patient; ${ }^{\star}=$ Patient maintained on same level of azathioprine; ${ }^{\star} \star=$ azathioprine dose reduced before post treatment ferrokinetics;

$\begin{aligned} & \mathrm{P}=\text { Predialysis patient; } \\ & \star \star \star\end{aligned}=$ azathioprine withdrawn prior to post treatment ferrokinetics; $\mathrm{D}=\mathrm{CAPD}$ patient; NA = result not available.

Reference ranges
Erythron transferrin uptake (ETU)

Marrow iron turnover (MIT)

Red cell iron turnover (RCIT)

Ineffective iron turnover (IIT)

$73-105 \mu \mathrm{mol} / 1$ blood $24 \mathrm{~h}$
$19-54 \mu \mathrm{mol} / 1$ blood $24 \mathrm{~h}$

Percentage ineffective iron turnover (IIT\%) $13-34 \%$

observed in those taking azathioprine following a change in the azathioprine dose for four patients. Azathioprine was withdrawn from cases 12 and 15 . Case 12 was originally receiving $150 \mathrm{mg}$ daily and case $1550 \mathrm{mg}$ daily. Both doses were withdrawn at six and three months, respectively, before the posttreatment ferrokinetic study was started. Cases 10 and 11 both had their azathioprine dose reduced one month before the post-treatment studies, case 11 from $100 \mathrm{mg}$ to $75 \mathrm{mg}$ daily, and case 10 from $150 \mathrm{mg}$ to $100 \mathrm{mg}$. These changes resulted in a substantial reduction in ineffective erythropoiesis in all four patients.

A close correlation between the ETU and MIT was recorded for all patients (figure). An increase in red cell survival (RCS) was recorded for two patients only (cases 4 and 12).

\section{Discussion}

Our results confirm the effectiveness of twice weekly subcutaneous injections of $r-\mathrm{HuEPO}$

Correlation between MIT and ETU.

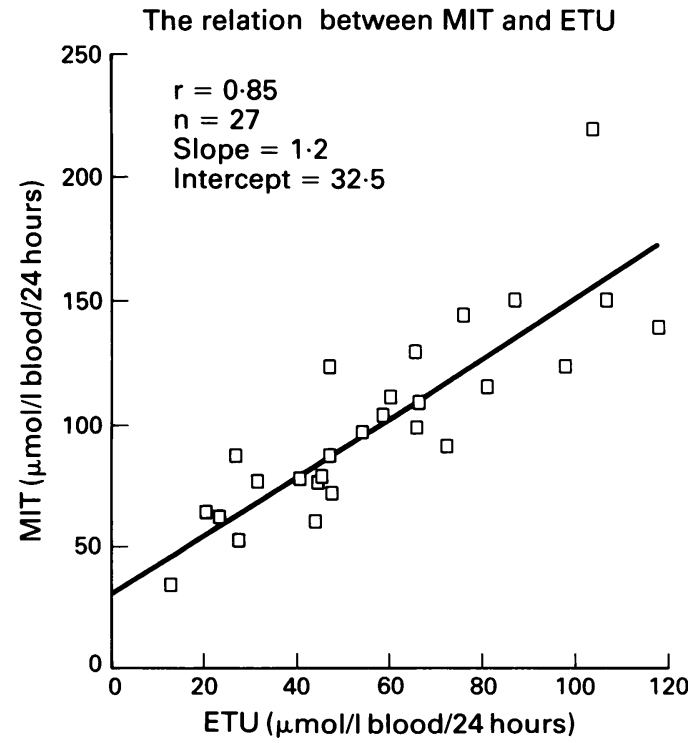

for treatment of both pre-dialysis and CAPD patients. Stimulation of erythropoiesis resulted in rapid mobilisation of iron stores, reflected by a sharp fall in serum ferritin concentration. All patients reported improvements in their sense of wellbeing, appetite, and activity levels. The benefits of treatment with subcutaneous $\mathrm{r}$-HuEPo have also been documented in several previous publications. ${ }^{24-26}$

Ferrokinetic studies showed that, within the time span of our study, expansion of the erythron by r-HuEPO, rather than an alteration in red cell survival, was primarily responsible for the initial improvement in the anaemia of both patient groups. Nevertheless, previous work has indicated that significant improvements in red cell survival may occur after nine to 15 months of treatment, the explanation for this later improvement remaining unclear. ${ }^{13}$

Total erythroid activity was expressed either as erythron transferrin uptake $(E T U)^{16}$ or marrow iron turnover (MIT). ${ }^{17}$ The close correlation observed between the ETU and MIT for the renal patients has also been reported for cases of myelofibrosis and myelodysplasia. ${ }^{27}$ The advantage of ETU measurements resides in the fact that a one day study period only is required, rather than the 10 to 14 days necessary for MIT measurements. The latter method, however, has the advantage of differentiating effective from ineffective erythropoiesis.

For patients to whom azathioprine was not given, $\mathrm{r}$-HuEPO produced an increase in both effective and ineffective erythropoiesis, the ratio of these two components remaining unaltered. Thus for these patients the resultant changes in erythroid activity were adequately defined by measurements of total erythropoiesis, expressed as either the MIT or ETU.

However, in patients receiving azathioprine these parameters did not provide a complete explanation of the functional changes accompanying r-HuEPo treatment. Azathoprine is metabolised to a purine antagonist which 
interferes directly with erythroid activity, producing the high level of ineffective erythropoiesis recorded for patients receiving this drug. This increase persisted for as long as the patients took azathoprine. Nevertheless, this group still derived benefit from treatment with r-HuEPO. The erythropoietin dose administered in this study seemed to be sufficient to overcome the inhibitory effect of azathioprine on erythroid activity, and promoted effective erythropoiesis to the level required for an improvement in anaemic state. A substantial reduction in ineffective erythropoiesis was shown only by those patients who either discontinued or reduced their azathioprine dose once they started r-HuEPO treatment. In such cases measurement of changes in total erythropoiesis provided only limited information on the functional erythropoietic activity. This was particularly evident when the increase in effective erythropoiesis was accompanied by a substantial decrease in ineffective erythropoiesis. As total erythropoiesis is the summation of effective and ineffective erythropoiesis, the resultant changes recorded for total erythroid activity in such cases may not accurately reflect the improvement indicated by the increase in red cell volume.

Ferrokinetic studies provide an insight into the functional changes following r-HuEPO treatment. However, to obviate any misinterpretation of data, stringent attention must always be paid to the effect of additional treatment which may itself influence erythroid activity.

The r-HuEPO for treatment of the pre-dialysis group was supplied by Boehringer Mannheim UK (Pharmaceuticals) Ltd, Simpson Parkway, Kirkton Campus, Livingston EH54 7BH; that for the CAPD group was supplied by Cilag Ltd, Saunderton, High Wycombe, Bucks HP14 14HJ.

We are grateful to Miss L Sweeney for her help in the preparation of the manuscript.

1 Eaves CJ, Eaves AC. Erythropoietin (Ep) dose-response curves for three classes of erythroid progenitors in normal human marrow and in patients with polycythaemia vera. Blood 1978;52:1196-210

2 Adamson JW, Eschbach J, Finch CA. The kidney and erythropoiesis. Am $\mathcal{F}$ Med 1968;44:725-33.

3 Eschbach JW, Adamson JW. Anaemia of end-stage renal disease (ESRD). Kidney Int 1985;28:1-5.

4 Chaplin H, Mollison PL. Red-cell lifespan in nephritis and in hepatic cirrhosis. Clin Sci 1953;12:351-60.

5 Eschbach JW, Funk D, Adamson JW, Kuhn I, Scribner BH, Finch CA. Erythropoiesis in patients with renal failure undergoing chronic dialysis. $N$ Engl $f$ Med 1967;276:653-8

6 Wallner SF, Vautrin.RM. Evidence that inhibition of erythropoiesis is important in the anaemia of chronic erythropoiesis is important in the anaemia of chronic

7 McGonigle RJS, Wallin JD, Shadduck RK, Fisher JW. Erythropoietin deficiency and inhibition of erythropoiesis in renal insufficiency. Kidney Int 1984;25:437-44.

8 Jacobs K, Showmaker C, Rudersdorf R, et al. Isolation and characterisation of genomic and cDNA clones of human erythropoietin. Nature 1985;313:806-10.

9 Lin F-K, Suggs S, Lin C-H, et al. Cloning and expression of the human erythropoietin gene. Proc Natl Acad Sci USA 1985;82:7580-4.

10 Winearls CG, Oliver DO, Pippard MJ, Reid C, Downing MR, Cotes PM. Effect of human erythropoietin derived from recombinant DNA on the anaemia of patients maintained by chronic haemodialysis. Lancet maintained 1986 ;i: $1175-8$.

11 Eschbach JW, Kelly MR, Haley NR, Abels RI, Adamson JW. Treatment of the anaemia of progressive renal failure with recombinant human erythropoietin. $N$ Engl $f \mathrm{Med}$ 1989;321:158-63.

12 Cotes PM, Pippard MJ, Reid CDL, Winearls CG, Oliver DO, Royston JP. Characterization of the anaemia of chronic renal failure and the mode of its correction by a preparation of human erythropoietin (r-HuEPO). $Q \mathcal{F}$
Med 1989;262:113-37.

13 Hughes RT, Cotes PM, Pippard MJ, et al. Subcutaneous administration of recombinant human erythropoietin to subjects on continuous ambulatory peritoneal dialysis: an subjects on continuous ambulatory peritoneal dialysis: an
erythrokinetic assessment. $\mathrm{Br} \mathcal{J}$ Haematol 1990; 75:268-73.

14 Macdougall IC, Cavill I, Davies ME, Hutton RD, Coles GA, Williams JD. Subcutaneous recombinant erythropoietin in the treatment of renal anaemia in CAPD poietin in the treatment of renal anaemia in CA
patients. Contribution to Nephrology 1989;76:219-26.

15 Macdougall IC, Davies ME, Hutton RD, et al. The treatment of renal anaemia in CAPD patients with recombinant human erythropoietin. Nephrol Dial Transplant 1990;5:950-5.

16 Cazzola M, Huebers HA, Sayers MH, MacPhail AP, Eng $M$, Finch CA. Transferrin saturation, plasma iron turnover and transferrin uptake in normal humans. Blood 1985;66:935-9.

17 Ricketts C, Jacobs A, Cavill I. Ferrokinetics and erythropoiesis in man: the measurement of effective erythropoiesis in man: the measurement of effective erythropoiesis, ineffective erythropoiesis and red

18 Cavill I. The preparation of ${ }^{50} \mathrm{Fe}$-labelled tranferrin for ferrokinetic studies. $\mathcal{f}$ Clin Pathol 1971;24:472-4.

19 International Committee for Standardization in Haematology. Standard techniques for the measurement of red cell and plasma volume. Br f Haematol 1973;25:801-14

20 International Committee for Standardization in Haematology. Recommended method for radioisotope red cell survival studies. Br f Haematol 1980;45:659-66.

21 Cavill I. Plasma clearance studies. In: Lewis SM, Bayly RJ, eds. Radionuclides in haematology. Edinburgh: Churchill Livingstone, 1986:214-44.

22 Dacie JV, Lewis SM. Practical Haematology. Edinburgh: Churchill Livingstone, 1984.

23 Waters HM. Serum ferritin and its enzyme-immunoassay. MSc Thesis, University of Manchester, 1985.

24 Bommer J, Ritz E, Weinreich R, et al. Subcutaneous erythropoietin. Lancet 1988;ii:406.

25 Boelart JR, Schurgers ML, Matthys EG, et al. Comparative pharmacokinetics of recombinant erythropoietin administered by the intravenous and intraperitoneal routes in continuous ambulatory peritoneal dialysis patients. Peritoneal Dial Intern 1989;9:95-8.

26 Stevens JM, Strong CA, Oliver DO, Winnearls CG, Cotes PM. Subcutaneous erythropoietin and peritoneal dialysis. Lancet 1989;i:1388-9.

27 Howarth JE, Waters HM, Hyde K, Shanks D, Geary CG. Comparative ferrokinetic study with initial and extended iron clearance models. $\mathcal{F}$ Clin Pathol 1991;44:395-9. 